\title{
Geographic and climatic factors related to a body-size cline in Dichroplus pratensis Bruner, 1900 (Acrididae, Melanoplinae)*
}

Accepted March 29, 2008

\section{Claudio J. Bidau and Dardo A. Martí}

(CJB)Laboratório de Biologia e Parasitologia de Mamíferos Silvestres Reservatórios, Instituto Oswaldo Cruz, FIOCRUZ, Rio de Janeiro, Brazil-CNPq. Email: bidau50@gmail.com

(DAM)Laboratorio de Genética Evolutiva, Universidad Nacional de Misiones, Posadas, CONICET, Argentina.

*This paper is for Rocío Hassan and Lili Castagno, our dear wives. Without them our work would have been impossible.

\begin{abstract}
We studied geographic body-size variation in males and females of 25 populations of the South American melanopline grasshopper Dichroplus pratensis Bruner, 1900, along more than 22 degrees of latitude(S) and between 0 and almost $2500 \mathrm{~m}$ of altitude. Using mean body length of each sex and factors obtained from PCA analyses of six morphometric linear characters, it was shown that $D$. pratensis follows the converse to Bergmann's rule, becoming smaller at higher latitudes and altitudes. Variability of body size increased with latitude and altitude in males and females. Body-size trends were statistically significantly correlated with ambient temperature (annual mean, minimum and maximum), precipitation (annual mean, minimum and maximum), and two estimators of seasonality, the difference between the maximum and minimum temperatures, and the difference between maximum and minimum precipitation for each locality; both nonparametric correlations were positive. Body size was also positively and significantly correlated with Actual Evapotranspiration (AET), a measure of primary productivity, and with Potential Evapotranspiration (PET), a measure of ambient energy, but not with water balance (WB). Some allometric relationships also showed geographic variation. We suggest that the observed decrease in size with latitude and the increase in morphological variability, are joint consequences of the shortening of the growing season towards the south, the increasing seasonality and climatic unpredictability, lower primary productivity (as represented by AET); and that the species exhibits protandry, which contributes in the south, to smaller and more variably sized males, and smaller but more constant body size in females.
\end{abstract}

\section{Key words}

body size, converse Bergmann's rule, Dichroplus pratensis, evapotranspiration, grasshopper, latitudinal gradient, precipitation, temperature

\section{Introduction}

In its classical sense, Bergmann's rule (Bergmann 1847) proposed that homeothermic animals display size clines; species within a genus are larger in cooler climates and smaller in warmer climates because of selection on the ability to thermoregulate (Bergmann 1847, James 1970, Blackburn et al. 1999, Ashton et al. 2000). Rensch (1938, 1959) and Mayr $(1956,1963)$ reformulated this ecogeographical rule for an empirical pattern independent of ecophysiological interpretations and applicable to intraspecific variation, and James (1970) stressed the importance of climatic factors in determining size clines. Most of the available literature deals with intraspecific body-size variation and many different hypotheses other than the original thermoregulation explanation, have been proposed to explain Bergmannian (and converse Bergmannian) body-size clines (Atkinson \& Sibly 1997; Ashton et al. 2000; Ashton 2001, 2002a,b; Ashton \& Feldman 2003; Meiri \& Dayan 2003; Blanckenhorn \& Demont 2004).

Although Bergmann's rule was originally proposed for homeotherms, Bergmannian (and converse Bergmannian) clines occur in invertebrate and vertebrate ectotherms (Ray 1960; Masaki 1967, 1978; Honek 1993; Atkinson 1994; Mousseau 1997; Arnett \& Gotelli 1999; Brisola Marcondes et al. 1999; Byers 2000; Huey et al. 2000; Smith et al. 2000; Trussell 2000; Roy \& Martien 2001; Ashton 2001, 2002a; Belk \& Houston 2002, Angilletta \& Dunham 2003, Ashton \& Feldman 2003; Heinze et al. 2003; Johansson 2003; Laugen et al. 2003, 2005; Blanckenhorn \& Demont 2004; Hausdorf 2003; Litzgus et al. 2004; Schäuble 2004; Bidau \& Martí 2007b; Peat et al. 2005; Cruz et al. 2005).

Converse Bergmannian clines are much more frequent in ectotherms than in endotherms, especially in insects (Brennan \& Fairbairn 1995, Mousseau 1997, Fischer \& Fiedler 2002, Blanckenhorn \& Demont 2004, Bidau \& Martí 2007b). Body sizes in insects probably respond to different ecophysiological factors and evolutionary pressures than those in endotherms. Several authors have proposed that size clines result from climatic selection on the duration of egg and nymphal development, which indirectly affects body size and can produce different geographic patterns according to the nature of the life cycle (Masaki 1967, 1978; Roff 1980; Blanckenhorn \& Demont 2004).

Species with ample latitudinal and/or altitudinal geographic ranges are useful models for the analysis of body-size distribution at the intraspecific level, as is the case for a number of South American grasshopper species of the melanopline genus Dichroplus (Cigliano \& Otte 2003, Bidau \& Martí2007a,b). Large distributions expose species to very different climatic conditions. Thus factors such as temperature and rainfall (Masaki 1967, 1978; Bidau \& Martí 2007a,b), but also seasonality (Murphy 1985, Chown \& Klok 2003), evapotranspiration (Rosenzweig 1968), primary productivity (Ashton et al. 2000), predation and competition pressure (Medina et al. 2007), etc., may combine to produce different kinds of size clines.

We studied the geographic distribution of body size in natural populations of Dichroplus pratensis Bruner, 1900 (Figs 2, 3; Plate IV), which has a very large latitudinal, longitudinal and altitudinal distribution in Argentina (Cigliano \& Otte 2003, Bidau \& Martí 2007a,b), and is thus an excellent model for the analysis of body-size distribution at the intraspecific level. We relate body-size clines to climatic variables in order to understand acridoid bodysize distribution in nature, and the relationship of these variables to development and sexual size dimorphism, which, until recently, were largely unknown for Neotropical species. 


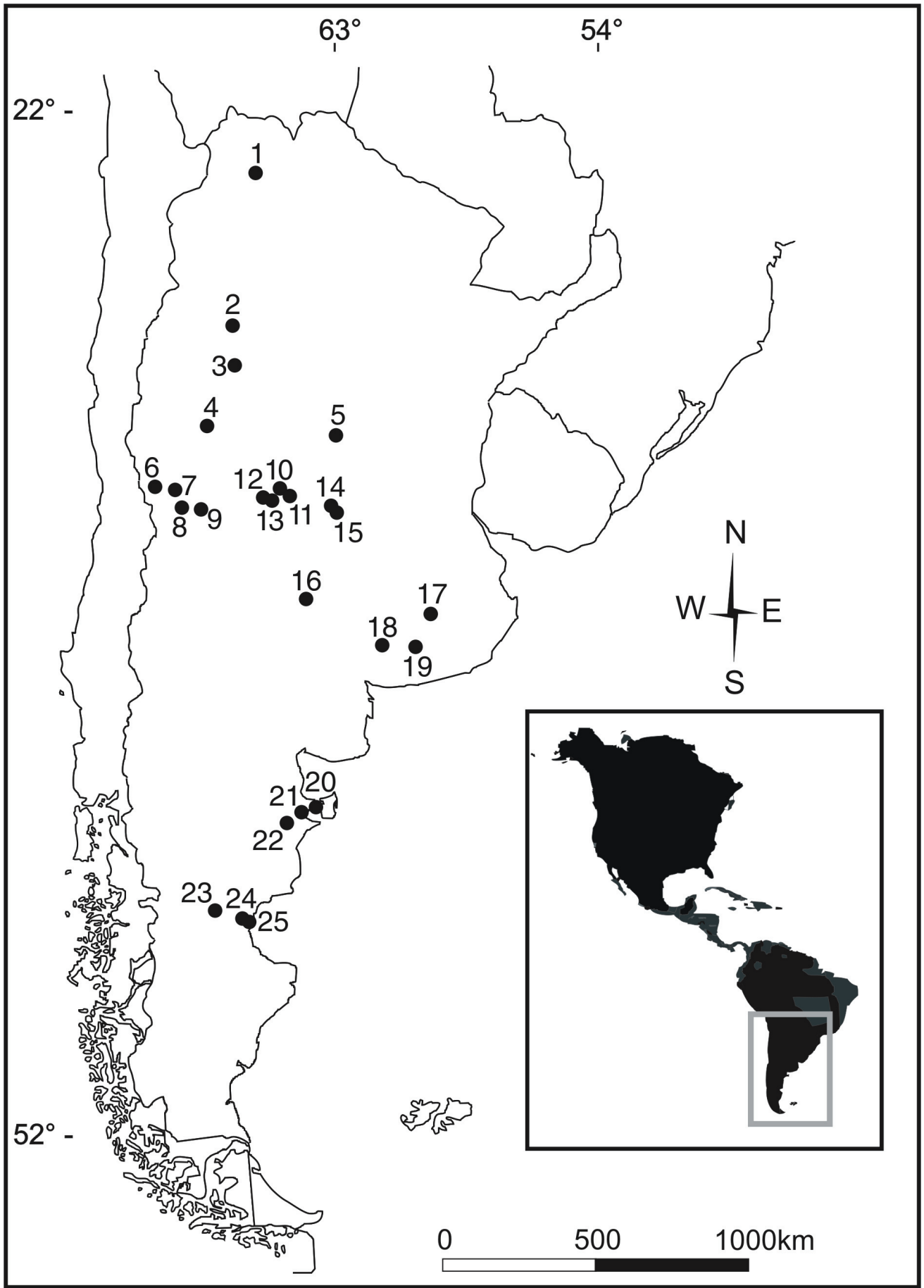

Fig. 1. Geographic distribution of 25 Argentine populations of $D$. pratensis analysed in this study.

\section{Materials and methods}

D. pratensis is a species belonging to the maculipennis group of Dichroplus grasshoppers (Cigliano \& Otte 2003). It is univoltine, shows obligatory egg diapause (Turk \& Barrera 1979), and is a nonselective polyphagous feeder (Cigliano \& Otte 2003, Bidau \& Martí 2006). We studied 621 adult specimens (343 males and 278 females) from 25 Argentine localities, spanning from lat $23.92^{\circ}$ $\mathrm{S}$ to lat $45.95^{\circ} \mathrm{S}$, and 0 to $2474 \mathrm{~m}$ above sea level (Fig. 1, Table 1). Six morphometric external characters were measured in dried specimens: a) total body length (BL) (Table 1; in order to avoid error resulting from the shrinking of the abdomen in dried specimens, this measurement was taken from the tip of the head to the distal end of the left hind femur when aligned parallel to the longitudinal axis of the body, as in Martí 2002), b) length of left hind femur (F3L), c) length of left hind tibia (T3L), d) length of tegmina (TeL), e) mid-dorsal length of pronotum (PL) and f) height of pronotum $(\mathrm{PH})$. Coefficients of variation for all characters were calculated as $\mathrm{CV}=\mathrm{s} \times 100 / \overline{\mathrm{x}}$ (Zar 1999). All size measurements were made in $\mathrm{mm}$, using high-precision calipers $(0.01 \mathrm{~mm})$.

Climatic data for all samples were obtained from Leemans \& Cramer (1991) (Table 1), and included: TMEA, Mean Annual Temperature; TMAX, Mean Maximum Monthly Temperature; TMIN, Mean Minimum Monthly Temperature (all in $\left.{ }^{\circ} \mathrm{C}\right)$; PANN, Total An- 
Table 1. Geographic coordinates, altitude, climatic parameters and mean adult body length of $D$. pratensis males and females from 25 Argentine localities. LAT: latitiude; LON: longitude; ALT: altitude. See Materials and Methods for other variable abbreviations and units.

\begin{tabular}{|c|c|c|c|c|c|c|c|c|c|c|c|c|c|c|c|c|c|c|}
\hline \multicolumn{19}{|c|}{ Independent variables } \\
\hline \multicolumn{5}{|c|}{$\begin{array}{c}\text { Geographic } \\
\text { variables }\end{array}$} & \multicolumn{12}{|c|}{ Climatic variables } & \multicolumn{2}{|c|}{$\begin{array}{l}\text { Body } \\
\text { length }\end{array}$} \\
\hline Locality & LAT & LON & ALT & TMEA & TMIN & TMAX & CVT & TM-m & PANN & PMIN & PMAX & CVP & PM-m & AET & PET & WB & MBL & FBL \\
\hline 1. Volcán & 23.92 & 65.45 & 2474 & 12.3 & 6.2 & 16.6 & 31.85 & 10.4 & 566 & 0 & 138 & 110.4 & 138 & 661 & 1218 & -1263 & 22.4 & 24.3 \\
\hline 2. E. Mazán & 28.73 & 66.48 & 646 & 16.5 & 8.1 & 23.7 & 34.8 & 15.6 & & 0 & 63 & 104.7 & 63 & 339 & 948 & -925 & 23.8 & 26.5 \\
\hline 3. Carrizal & 28.90 & 67.55 & 522 & 13.3 & 6.1 & 20.2 & 38.7 & 14.1 & 164 & 0 & 44 & 110.6 & 44 & 293 & 1013 & -960 & 24.0 & 28.2 \\
\hline 4. Las Juntas & 30.68 & 67.58 & 203 & 17.8 & 9.3 & 26.0 & 34.3 & 16.7 & 181 & 0 & 41 & 98.8 & 41 & 221 & 949 & -926 & 21.8 & 25.7 \\
\hline 5. C. Machado & 31.46 & 63.58 & 314 & 18.0 & 11.0 & 24.9 & 28.0 & 13.9 & 742 & 14 & 109 & 63.7 & 95 & 794 & 821 & -56 & 25.6 & 27.7 \\
\hline 6. Guido & 32.86 & 69.25 & 2099 & 15.1 & 6.9 & 22.8 & 38.7 & 15.9 & 384 & 10 & 86 & 85.3 & 76 & 297 & 1007 & -691 & 25.1 & 26.9 \\
\hline 7. Potrerillos & 32.93 & 69.18 & 1469 & 15.1 & 6.9 & 22.8 & 38.7 & 15.9 & & 9 & 30 & 35.0 & 21 & 297 & 1007 & -691 & 23.8 & 23.8 \\
\hline 8. Cacheuta & 33.03 & 69.12 & 1310 & 15.1 & 6.9 & 22.8 & 38.7 & 15.9 & 225 & 9 & 30 & 35.0 & 21 & 329 & 1105 & -758 & 23.5 & 24.9 \\
\hline 9. Compuertas & 33.05 & 69.07 & 1063 & 15.1 & 6.9 & 22.8 & 38.7 & 15.9 & 22 & 9 & 30 & 35.0 & 21 & 329 & 1105 & -758 & 26.4 & 27.2 \\
\hline 10. L & 33.13 & 65.08 & & & & & & & & 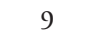 & & & 8 & & 833 & & 4.2 & \\
\hline 11. Achiras & 33.15 & 65.00 & 838 & 14.7 & 6.9 & 22.1 & 38.1 & 15.2 & 6 & 0 & 107 & 68.3 & 98 & 694 & 833 & -123 & 23.8 & 26.7 \\
\hline 12. Saladillo & 33.21 & 65.87 & 840 & 14.6 & 6.7 & 22.1 & 38.9 & 15.4 & 604 & 8 & 108 & 71.7 & 100 & 595 & 829 & -179 & 25.0 & 25.7 \\
\hline 13. El Morro & 33.22 & 65.48 & 993 & 15.7 & 7.9 & 23.3 & 35.9 & 15.4 & & 8 & 108 & 71.7 & 100 & 645 & 842 & -179 & 24.7 & 24.5 \\
\hline 14. La Granja & 33.50 & 63.28 & 125 & 16.8 & 9.2 & 24.4 & 33.1 & 15.2 & 774 & 16 & 111 & 56.8 & 95 & 856 & 1043 & -171 & 26.0 & 26.8 \\
\hline 15. Manantiales & 33.53 & 63.33 & 134 & 16.8 & 9.2 & 24.4 & 33.1 & 15.2 & 774 & 16 & 111 & 56.8 & 95 & 856 & 1043 & -171 & 26.1 & 26.9 \\
\hline 16. Don Tomás & 36.68 & 64.33 & 175 & 15.6 & 7.5 & 24.2 & 39.8 & 16.7 & 599 & 15 & 80 & 52.1 & 65 & 570 & 754 & -106 & 24.2 & 25.4 \\
\hline 17. Olavarría & 36.92 & 60.12 & 162 & 14.0 & 7.2 & 21.8 & 38.2 & 14.6 & 831 & 38 & 115 & 29.2 & 77 & 793 & 892 & -88 & 22.6 & 24.3 \\
\hline 18. C. Pringles & 37.97 & 61.37 & 251 & 14.0 & 7.0 & 22.1 & 39.4 & 15.1 & & 22 & 98 & 36.6 & 76 & 695 & 882 & -52 & 23.4 & 25.3 \\
\hline 19. C. Ceferino & 38.10 & 61.80 & 456 & 13.8 & 6.6 & 21.9 & 41.0 & 15.3 & & 19 & 91 & 38.7 & 72 & 617 & 894 & -125 & 23.3 & 25.2 \\
\hline 20. I.Ameghino & 42.50 & 64.53 & 55 & 13.2 & 6.6 & 19.4 & 35.9 & 12.8 & 204 & 9 & 27 & 36.4 & 18 & 226 & 567 & -344 & 22.2 & 24.1 \\
\hline 21. P .Madryn & 42.81 & 65.05 & 18 & 13.3 & 6.4 & 19.8 & 37.4 & 13.4 & 180 & 8 & 23 & 28.9 & 15 & 200 & 567 & -373 & 22.6 & 25.2 \\
\hline 22. Km 1430 & 43.06 & 65.20 & 36 & 13.1 & 6.4 & 9.4 & 36.8 & 13.0 & 180 & 8 & 23 & 28.9 & 15 & 210 & 553 & -354 & 22.5 & 22.7 \\
\hline 23. L. Musters & 45.50 & 69.13 & 261 & 10.3 & 3.5 & 16.6 & 48.6 & 13.1 & 110 & 5 & 18 & 47.2 & 13 & 203 & 477 & -289 & 19.5 & 23.5 \\
\hline 24. D.Argentina & 45.78 & 67.67 & 326 & 11.1 & 5.1 & 17.1 & 41.1 & 12.0 & 181 & 0 & 41 & 98.8 & 41 & 216 & 468 & -210 & 19.3 & 22.2 \\
\hline 25. V.Rada Tilly & 45.95 & 67.53 & 0 & 10.7 & 4.9 & 16.4 & 40.3 & 11.5 & 144 & 5 & 26 & 50.3 & 21 & 216 & 468 & -210 & 18.9 & 23.2 \\
\hline
\end{tabular}

nual Precipitation; PMAX, Mean Maximum Monthly Precipitation, and PMIN, Mean Minimum Monthly Precipitation (all in mm). Seasonality was estimated as the coefficients of variation of TMEA (CVT), the difference between TMAX and TMIN (TM-m), the CV of mean annual precipitation (CVP), and the difference between maximum and minimum monthly precipitation (PM-m). Actual Evapotranspiration (AET, an estimator of primary productivity), Potential Evapotranspiration (PET, a measure of ambient energy) and Water Balance (WB), were obtained for each locality (Table 1). We used vectors, databases and maps for AET, PET and WB from Ahn \& Tateishi (1994a,b) (Table 2). Data analysis was performed with Geomatica FreeView V. 10.0 software by PCI Geomatics, Ontario, Canada. www.pcigeomatics.com.

Normality of data was estimated through the KolmogorovSmirnov test (Zar 1984). All measurements were log-transformed, except for proportions to which the arsin (angular) transformation (Steel \& Torrie 1980) was applied. Latitude (LAT) and longitude (LON) were converted to decimal units. Principal Components Analysis (PCA) was employed to analyze the relationship between body size and the geographic and climatic variables considered. Factors extracted in each analysis were rotated with the VARIMAX procedure with Kaiser Normalization and used as dependent variables in correlation/regression tests.
Table 2. Principal Components Analysis of morphological data of populations of $D$. pratensis from Argentina. Three factors were extracted and rotated with the VARIMAX procedure with Kaiser Normalization for 12 morphometric variables of males and females (see Materials and Methods for explanation of variables). Values correspond to correlation coefficients between variables and factors. Relatively high loadings ( $|r|>0.5)$ are marked with an asterisk. \%VE: $\%$ total variance explained.

\begin{tabular}{lccc}
\hline & \multicolumn{3}{c}{ Principal Component } \\
\hline LOGBLM & 1 & 2 & 3 \\
LOGF3M & $0.887^{*}$ & 0.353 & 0.253 \\
LOGT3M & $0.792^{*}$ & 0.285 & 0.445 \\
LOGTEM & $0.664^{*}$ & 0.224 & 0.486 \\
LOGPLM & $0.894^{*}$ & -0.004 & $0.727^{*}$ \\
LOGPHM & $0.828^{*}$ & 0.377 & 0.197 \\
LOGBLF & 0.465 & 0.433 & 0.007 \\
LOGF3F & 0.254 & $0.828^{*}$ & 0.189 \\
LOGT3F & 0.020 & $0.866^{*}$ & 0.388 \\
LOGTEF & 0.233 & $0.855^{*}$ & 0.444 \\
LOGPLF & 0.445 & 0.236 & $0.924 *$ \\
LOGPHF & 0.492 & $0.838^{*}$ & -0.010 \\
\%VE & 68.78 & $0.795^{*}$ & -0.242 \\
\hline
\end{tabular}


Table 3. Results of multiple regression (stepwise backward) of five estimators of body size $v$ s latitude, longitude, and altitude in 25 Argentine populations of D. pratensis. $\mathrm{r}^{2}$ : coefficient of determination; F(df): F-statistic (degrees of freedom); p: probability; Coefficients: regression coefficients; t: Student's t-statistic; Partial correlations: partial correlation coefficients from the multiple regression analyses; MBL, FBL: mean male and female body lengths; PC1, PC2, PC3: the first three Principal Components of the PCA shown in Table 2.

\begin{tabular}{|c|c|c|c|c|c|c|c|c|}
\hline \multicolumn{9}{|c|}{ Multiple regression } \\
\hline Dependent variable & $\mathrm{r}^{2}$ & $\mathrm{~F}(\mathrm{df})$ & $\mathrm{p}$ & Predictors & Coefficients & $\mathrm{t}$ & $\mathrm{p}$ & Partial correlations \\
\hline \multirow[t]{3}{*}{ LogMBL } & \multirow{3}{*}{0.51} & \multirow{3}{*}{$\begin{array}{r}11.50 \\
(2,22)\end{array}$} & \multirow{3}{*}{$<0.001$} & (constant) & 1.599 & 30.19 & $<0.001$ & \\
\hline & & & & LAT & $-6.07 * 10^{-3}$ & -4.58 & $<0.001$ & -0.70 \\
\hline & & & & ALT & $-2.30 * 10^{-5}$ & -1.97 & 0.062 & -0.39 \\
\hline \multirow[t]{3}{*}{ LogFBL } & \multirow{3}{*}{0.58} & \multirow{3}{*}{$\begin{array}{r}15.30 \\
(2,22)\end{array}$} & \multirow{3}{*}{$<0.001$} & (constant) & 1.587 & 44.82 & $<0.001$ & \\
\hline & & & & LAT & $-4.79 * 10^{-3}$ & -5.41 & $<0.001$ & -0.76 \\
\hline & & & & ALT & $-2.16 * 10^{-5}$ & -2.76 & 0.011 & -0.51 \\
\hline \multirow[t]{2}{*}{ PC1 } & \multirow{2}{*}{0.36} & \multirow{2}{*}{$\begin{array}{r}12.69 \\
(1,23)\end{array}$} & \multirow{2}{*}{0.002} & (constant) & 3.659 & 3.52 & 0.002 & \\
\hline & & & & LAT & -0.103 & -3.56 & 0.002 & -0.60 \\
\hline \multirow[t]{2}{*}{ PC2 } & \multirow{2}{*}{0.54} & \multirow{2}{*}{$\begin{array}{r}9.41 \\
(1,23)\end{array}$} & \multirow{2}{*}{0.005} & (constant) & 3.307 & 3.03 & 0.006 & \\
\hline & & & & LAT & -0.093 & -3.07 & 0.005 & -0.54 \\
\hline \multirow[t]{2}{*}{ PC3 } & \multirow{2}{*}{0.36} & \multirow{2}{*}{$\begin{array}{r}12.76 \\
(1,23)\end{array}$} & \multirow{2}{*}{0.002} & (constant) & 0.606 & 2. 60 & 0.017 & \\
\hline & & & & ALT & $-9.07 * 10^{-4}$ & -3.57 & 0.002 & -0.60 \\
\hline
\end{tabular}
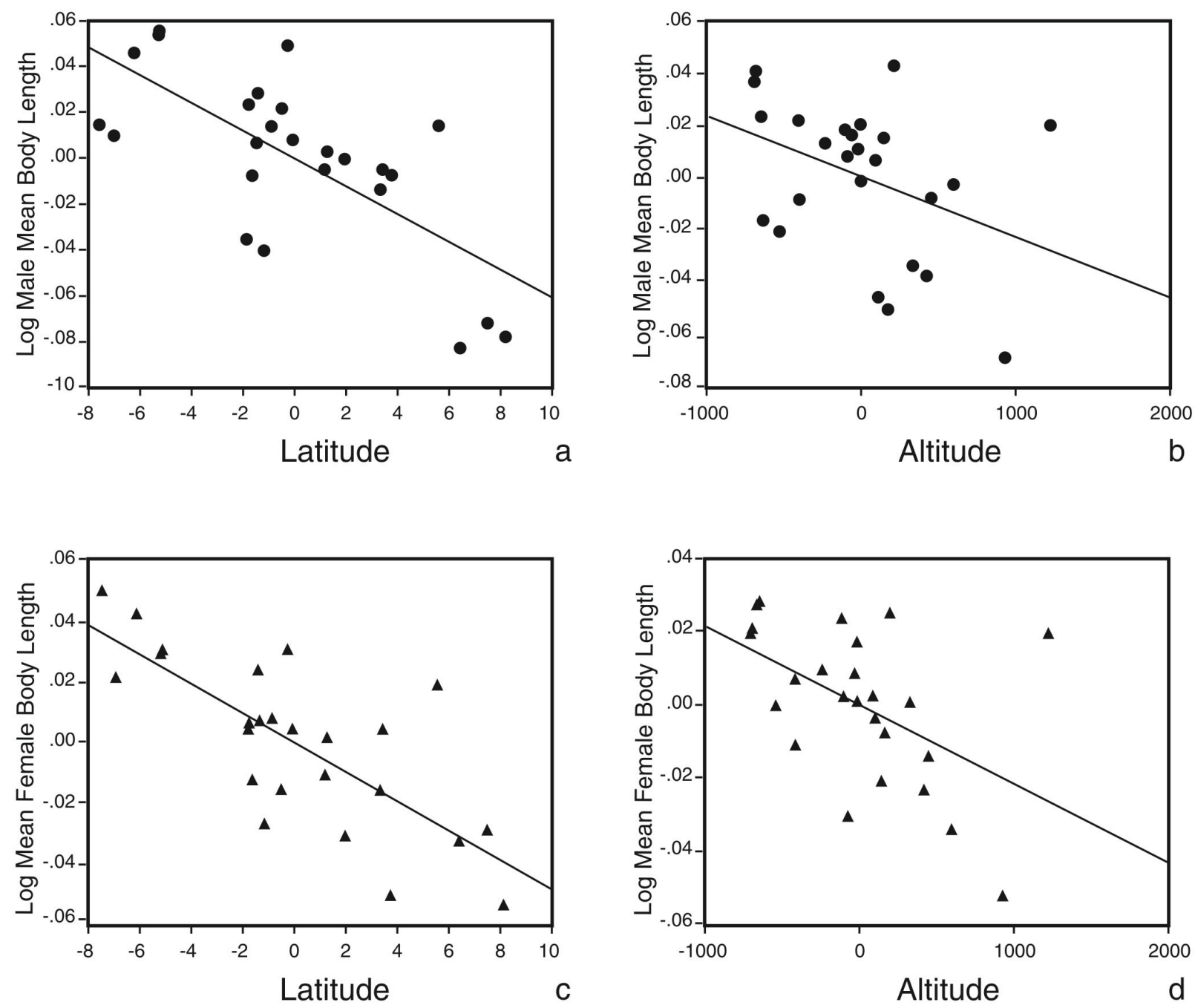

Fig. 2. Partial regression plots of male and female body length ( $\mathrm{mm}$ ) as a function of latitude (a, c) and altitude (b, d), in D. pratensis. $\mathrm{X}$-axis scales resulted from the transformation of actual latitude and altitude values shown in Table 1. 


\section{Results}

Geographic variation of body size in D. pratensis. - Multiple stepwise backward regression analyses of mean body length of males and females, and the first three regression factors obtained by PCA (Table 2) against LAT, LON and ALT, showed that in both sexes BL decreases with increasing latitude and less significantly so with altitude (Table 3, Fig. 2). When the dependent variable was one of the principal components, LAT was the main predictor of body size for PC1 and PC2, while ALT was this for PC3 (Table 3). PC3 is basically a 'tegmina length component' (Table 2) thus, length of tegmina appears to be the main character underlying the altitudinal cline in D. pratensis (see below).

Correlations of body size with climatic factors. - Latitude or altitude per se have no explanatory power on the origin of size clines (Hawkins \& Diniz Filho 2004); thus, geographic body sizevariation in $D$. pratensis was analyzed in relation to climatic parameters and estimators of climate variability (Table 4). Three estimators of body size (MBL, FBL and PC1) showed statistically significant positive correlations with temperature parameters and with TM-m (Table 4). However, all temperature parameters are colinear with latitude, and TM-m is significantly correlated with altitude (Table 5).

Except for PC2, all body-size estimators were positively correlated with annual precipitation, and some, with PMIN and PMAX (Table 4). The former three precipitation variables are not correlated with latitude or with altitude in the studied area (Table 5). Only PC2 was correlated with CVP, while male and female body size were significantly positively correlated with PM-m. Both measures of precipitation variability are negatively correlated with LAT, while CVP is also positively correlated with ALT. Both PET and AET were good predictors of body size in D. pratensis (Table 4). Of these, only AET is not correlated either with latitude or altitude in our sampling area (Table 5).
Geographic variation of allometric relationships-As the results from the correlation analyses between factors obtained by PCA and geographic variables showed, it appeared that not all the analyzed morphometric characters followed the same geographic trends as total body length. Since this could be a result of varying allometric relationships, we analyzed first the nature of allometries in $D$. pratensis and second, the relationships of these allometries with geographic parameters. Table 6a shows the slopes of linear regression lines between the means of five morphometric characters and body length in both sexes of $D$. pratensis. F3L and T3L exhibit negative allometry in both sexes, being more evident in females (Table $6 a)$. Individually, these variables showed negative nonsignificant latitudinal clines, except for female F3L $(\mathrm{r}=-0.403, \mathrm{p}=0.046)$. Tegmina length was basically isometric with body length in males, but strongly negatively allometric in females (Table 6a). In males, TeL was negatively, but nonsignificantly correlated with either LAT or ALT; in females, positive (LAT) and negative (ALT) correlations were observed, although none of them were statistically significant. Pronotum measurements were positively allometric in males but basically isometric in females (Table 6a). Furthermore, PL and PH showed negative latitudinal clines in males and females.

We tested the proportions between F3L, T3L, TeL, PL and PH (both sexes) and BL, vs LAT, LON and ALT. As shown in Table 6b, males and females show comparable geographic trends. However, the proportions of F3L, T3L and TeL increase with LAT and decrease with ALT, while the opposite occurs with both pronotum measurements (Table 6b).

\section{Discussion}

The existence of intraspecific converse Bergmannian clines in insects has been cited for a number of different taxa, although few studies deal with Orthoptera (Blanckenhorn \& Demont 2004). In

Table 4. Nonparametric (Spearman's rho) correlation coefficients between body-size estimators and climatic factors in 25 populations of $D$. pratensis. Probabilities just below. See Materials and Methods for variable abbreviations. NS: statistically nonsignificant.

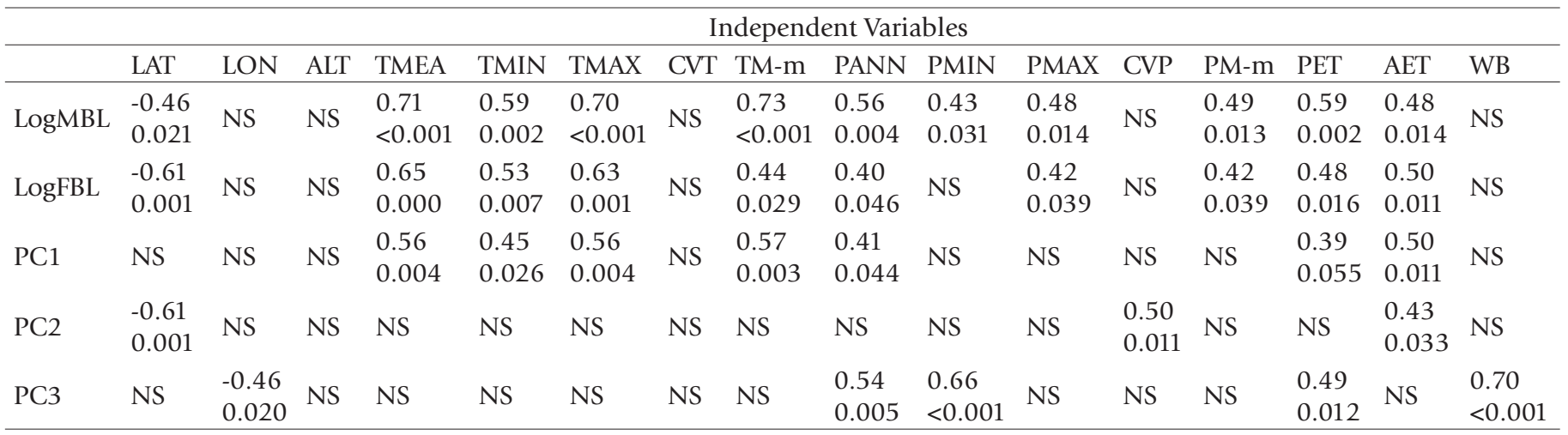

Table 5. Nonparametric (Spearman's rho) correlation coefficients between climatic factors and geographical variables in 25 populations of $D$. pratensis. Probabilities just below. See Materials and Methods for variable abbreviations. NS: statistically nonsignificant.

\begin{tabular}{|c|c|c|c|c|c|c|c|c|c|c|c|c|c|}
\hline \multicolumn{14}{|c|}{ Independent Variables } \\
\hline & TMEA & TMIN & TMAX & CVT & TM-m & PANN & PMIN & PMAX & CVP & PM-m & PET & AET & WB \\
\hline Lat & $\begin{array}{l}-0.57 \\
0.003\end{array}$ & $\begin{array}{l}-0.43 \\
0.033\end{array}$ & $\begin{array}{l}-0.52 \\
0.008\end{array}$ & $\begin{array}{c}0.47 \\
0.017\end{array}$ & $\begin{array}{c}0.47 \\
0.019\end{array}$ & NS & NS & $\begin{array}{l}-0.38 \\
0.061\end{array}$ & $\begin{array}{l}-0.54 \\
0.006\end{array}$ & $\begin{array}{l}-0.41 \\
0.046\end{array}$ & $\begin{array}{c}-0.71 \\
<0.001\end{array}$ & NS & $\begin{array}{c}0.43 \\
0.032\end{array}$ \\
\hline Lon & NS & NS & NS & NS & NS & $\begin{array}{c}-0.70 \\
<0.001\end{array}$ & $\begin{array}{l}-0.63 \\
0.001\end{array}$ & $\begin{array}{l}-0.54 \\
0.006\end{array}$ & NS & $\begin{array}{l}-0.40 \\
0.047\end{array}$ & NS & $\begin{array}{l}-0.64 \\
0.001\end{array}$ & $\begin{array}{l}-0.72 \\
<0.001\end{array}$ \\
\hline Alt & NS & NS & NS & NS & $\begin{array}{c}0.53 \\
0.007\end{array}$ & NS & NS & NS & $\begin{array}{c}0.45 \\
0.026\end{array}$ & NS & $\begin{array}{c}0.58 \\
0.002\end{array}$ & NS & $\begin{array}{l}-0.43 \\
0.032\end{array}$ \\
\hline
\end{tabular}


Table 6. Static allometric relationships of five morphometric characters in D. pratensis. a. Slopes of linear regression lines; b. Nonparametric correlation coefficients (Spearmn's rho) between male and female proportions between morphometric characters and body length (arsin transformation), and geographic parameters. See Materials and Methods for abbreviations of variables. NS: statistically non-significant; M: male; F: female.

\begin{tabular}{lcc}
\hline a. & \multicolumn{2}{c}{ Slope of linear regression line } \\
\hline Relationship & Males & Females \\
\hline F3L/BL & 0.84 & 0.62 \\
T3L/BL & 0.76 & 0.47 \\
TeL/BL & 1.01 & 0.62 \\
PL/BL & 1.21 & 0.99 \\
PH/BL & 1.14 & 1.07 \\
\hline
\end{tabular}

\begin{tabular}{lccc}
\hline b. & \multicolumn{3}{c}{ Spearman's correlation coefficient } \\
(probability)
\end{tabular}

the case of the Acrididae, only four species, Chorthippus brunneus and Omocestus viridulus in the Northern Hemisphere, and D. pratensis and D. vittatus in South America, have been analysed with respect to the relationship between body size, growth and external factors such as temperature (Telfer \& Hassall 1999; Berner et al. 2004; Berner \& Blanckenhorn 2006; Bidau \& Martí 2007a,b; Walters \& Hassall 2006). The problem of explaining size clines in insects (and in ectotherms in general) is directly related to the so-called temperature-size rule which was first analysed by Bergmann (1847) in endotherms. However, it was found that ectotherms, although they do not metabolically regulate their body temperature, frequently follow size-temperature rules, either Bergmannian or converse Bergmannian (Ray 1960, Atkinson 1994, Atkinson \& Sibly 1997, Arnett \& Gottelli 1999, Ashton 2002a, Bernardo \& Reagan-Wallin 2002, Angilleta \& Durham 2003, Ashton \& Feldman 2003, Blanckenhorn \& Demont 2004, Walters \& Hassall 2006). While it has been repeatedly observed that ectotherms grow larger (although more slowly) when reared at low temperatures (reviewed by Atkinson 1994), most insects follow the converse of Bergmann's rule: body size is larger at higher, than at lower, temperatures (Masaki 1967, 1978; Blanckenhorn \& Demont 2004; Bidau \& Martí 2007a,b).

The positive growth-temperature relationship is the case with D. pratensis reported here and in a previous work (Bidau \& Martí 2007a) and also, of a closely related species, D. vittatus (Bidau \& Martí 2007b). The latitudinal decrease in size of D. pratensis parallels the corresponding decrease in mean, minimum and maximum ambient temperatures; however, temperature per se cannot explain the converse Bergmannian size cline unless temperature indirectly affects some other biological parameters independent of thermoregulation. In univoltine insects of wide latitudinal and altitudinal distribution such as $D$. pratensis, duration of the growing season (thus ambient temperature) can be a powerful limiting factor to body size (Masaki 1967, Roff 1980).

D. pratensis goes through an obligatory egg diapause, with only one generation peryear, resulting in an arrest of embryogenesis at the end of anatrepsis, with eggs initiating diapause for several months. The number of months varies in different geographic regions (Turk \& Barrera 1979). Obligatory diapause and one generation per year represent the normal condition of $D$. pratensis natural populations (Cigliano \& Otte 2003, Bidau \& Martí 2007b). The number of nymphal stages is five in males and six in females (with a further facultative stage), and the duration of the nymphal cycle varies negatively with temperature (Turk \& Barrera 1979).

Among D. pratensis populations, we observed significant positive correlations of body size with temperature (TMEA, TMIN and TMAX). These three parameters are significantly correlated with latitude in our sample (Table 5). Temperature per se may explain Bergmann's rule in ectotherms (Atkinson \& Sibly 1997, Blanckenhorn \& Demont 2004), but not its converse, except when temperature operates as an

indirect selective factor on body size by limiting nymphal growth and development (Masaki 1967). Converse Bergmannian patterns are probably adaptive (Masaki 1967, 1978, Roff 1980, Blanckenhorn \& Fairbairn 1995, Blanckenhorn \& Demont 2004), and essentially depend on constraints imposed by season length on growth and development (Masaki 1967, Roff 1980, Blanckenhorn \& Demont 2004, Bidau \& Martí 2007b). In D. pratensis (and D. vittatus, Bidau \& Martí 2007b), the converse Bergmannian cline is probably, in part, a consequence of these constraints. However, although an altitudinal consistent but nonsignificant body-size pattern was found in $D$. pratensis, temperature parameters were not correlated with altitude (Table 5). Thus other climatic factors like precipitation may play an additional role in the latitudinal converse clines of $D$. pratensis.

In this study, body size and rainfall estimates tended to be positively correlated (Table 4), although only PMAX showed a significantly negative correlation with latitude (Table 5). Since D. pratensis is an ecological generalist occurring in both dry and relatively humid habitats, it is probable that larger individuals occur in areas of higher precipitation which coincide with ecologically central environments (Bidau \& Martí, 2002). In fact, temperature parameters are positively correlated with rainfall parameters within the studied range. For example, TMEA and PANN showed a Spearman correlation coefficient of $\rho=0.525, p=0.007$. Thus, larger individuals are predicted, in principle, in areas of higher mean temperatures and higher total annual precipitation.

Furthermore, two noncorrelated seasonality estimates, TM-m and PM-m were positively correlated with body size (Table 4), although their relationship to LAT was opposite (Table 5). A multiple regression between male body size and TM-m and PM-m, produced the following results: $\mathrm{r}^{2}=0.574, \mathrm{~F}=14.844, \mathrm{p}<0.001$; partial correlations, TM-m $(0.676, \mathrm{p}=0.000)$ and PM-m $(0.539, \mathrm{p}=0.007)$. In the case of females, $\mathrm{r}^{2}=0.401, \mathrm{~F}=7.360, \mathrm{p}=0.004$; partial correlations, TM-m (0.537, $\mathrm{p}=0.007)$ and PM-m (0.421, $\mathrm{p}=0.041)$. Accordingly, 
larger $D$. pratensis individuals should also occur in more seasonal environments that also show higher mean annual temperature and total rainfall in the studied area. Thus, although lower temperature and precipitation may produce smaller individuals in general, variability of these parameters probably favors larger body sizes.

Regarding evapotranspiration, body size was significantly correlated with AET and PET (Table 4). AET is an estimate of primary productivity (Rosenzweig 1968) and in our study it was not correlated with latitude (Table 5). It thus seems reasonable that larger body sizes occur at localities with higher AET values, which are also significantly positively correlated with TMEA, PANN and PM-m, although not with TM-m.

We conclude that converse latitudinal body-size clines in $D$. pratensis are probably influenced by a set of several climatic factors, some of which are correlated with latitude, and others, not. These factors are: annual mean temperature and rainfall, which probably limit the length of the growing season; seasonality, that possibly selects for larger body sizes in more heterogeneous and less-predictable environments, and primary productivity (as estimated by AET) that affects resources availability.

\section{Acknowledgements}

CJB is very grateful to the Conselho Nacional de Desenvolvimento Científico e Tecnológico (CNPq) of Brazil for a Visiting Researcher's grant that allowed the completion of this paper and to his dear family and all Brazilian friends that supported his research during hard times. Financial support from CNPq (grant 480596/2007-7), FAPERJ (grant APQ1 32252007) and FIOCRUZ, all from Brazil, is gratefully acknowledged. The authors are also grateful to Dr. Rocío Hassan for kindly reviewing the manuscript.

\section{References}

Ahn C.-H., Tateishi R. 1994a. Development of a global 30-minute grid Potential Evapotranspiration data set. Journal of the Japanese Society of Photogrammetry and Remote Sensing 33: 12-21.

Ahn C.-H., Tateishi R. 1994b. Estimation of Potential Evapotranspiration for Global Data Sets.Proc. ISPRS Communications IV Symposium, Mapping and Geographic Information Systems, May 31 - June 3, Athens, Georgia USA 30/4: 586-593.

Angilletta M.J.Jr., Dunham A.E. 2003. The temperature-size rule in ectotherms: simple evolutionary explanations may not begeneral. American Naturalist 162: 332-342.

Arnett A.E., Gotelli N.J. 1999. Bergmann's rule in the ant lion Myrmeleon immaculatus DeGeer (Neuroptera: Myrmeleontidae): geographic variation in body size and heterozygosity. Journal of Biogeography 26: $275-283$.

Ashton K.G. 2001. Body size variation among mainland populations of the western rattlesnake (Crotalus viridis). Evolution 55: 2523-2533.

Ashton K.G. 2001. Are ecological and evolutionary rules being dismissed prematurely? Diversity and Distributions 7: 289-295.

Ashton K.G. 2002a. Do amphibians follow Bergmann's rule? Canadian Journal of Zoology 80: 708-716.

Ashton K.G. 2002b. Patterns of within-species body size variation of birds: strong evidence for Bergmann's rule. Global Ecology and Biogeogeography 11: 505-523.

Ashton K.G. \& Feldman C.R. 2003. Bergmann's rule in nonavian reptiles: turtles follow it, lizards and snakes reverse it. Evolution 57: 11511163.

Ashton K.G., Tracy M.C., de Queiroz A. 2000. Is Bergmann's rule valid for mammals? The American Naturalist 156: 390-415.

Atkinson D. 1994. Temperature and organism size - a biological rule for ectotherms? Advances in Ecological Research 25: 1-58.
Atkinson D., Sibly R.M. 1997. Why are organisms usually bigger in colder environments? Making sense of a life history puzzle. Trends in Ecology and Evolution 12: 235-239.

Belk M.C., Houston D.D. 2002. Bergmann's rule in ectotherms: a test using freshwater fishes. American Naturalist 160: 803-808.

Bergmann C. 1847. Ueber die Verhältnisse der Wärmeökonomie der Thiere zu ihrer Grösse. Gottinger studien v.3, pt.1: 595-708.

Bernardo J. \& Reagan-Wallin N.L. 2002. Plethodontid salamanders do not conform to "general rules" for ectotherm life histories: insights from allocation models about why simple models do not make accurate predictions. Oikos 97: 398-414.

Berner D., Blanckenhorn W.U. 2006. Grasshopper ontogeny in relation to time constraints: adaptive divergence and stasis. Journal of Animal Ecology 75: 130-139.

Berner D., Körner C., Blanckenhorn W.U. 2004. Grasshopper populations across $2000 \mathrm{~m}$ of altitude: is there life history adaptation? Ecography 27: 733-740.

Bidau C.J., Martí D.A. 2000. Meiosis and the Neo-XY system of Dichroplus vittatus (Melanoplinae, Acrididae): a comparison between sexes. Genetica 110: 185-194.

Bidau C.J. \& Martí D.A. 2002. Geographic distribution of Robertsonian fusions in Dichroplus pratensis (Melanoplinae, Acrididae): the central marginal hypothesis reanalysed. Cytogenetic and Genome Research 96: 66-74.

Bidau C.J., Martí D.A. 2007a. Clinal variation of body size in Dichroplus pratensis (Orthoptera: Acrididae): inversion of Bergmann's and Rensch's Rules. Annals of the Entomological Society of America 100: 850-860.

Bidau C.J., Martí D.A. 2007b. Dichroplus vittatus Bruner 1900 (Acrididae, Melanoplinae) follows the converse to Bergmann's rule although male morphological variability increases with latitude. Bulletin of Entomological Research 97: 69-79.

Blackburn T.M., Gaston K.J., Loder N. 1999. Geographic gradients in body size: a clarification of Bergmann's rule. Diversity and Distributions 5: 165-174.

Blanckenhorn W.U., Fairbairn D.J. 1995. Life history adaptation along a latitudinal cline in water striders. Journal of Evolutionary Biology 8: 21-41.

Blanckenhorn W.U., Demont M. 2004. Bergmann and converse Bergmann latitudinal clines in arthropods: two ends of a continuum? Integrative and Comparative Biology 44: 413-424.

Brennan J.M., Fairbairn D.J. 1995. Clinal variation in morphology among eastern populations of the waterstrider, Aquarius remigis Say (Hemiptera, Gerridae). Biological Journal Linnean Society 54: 151-171.

Brisola Marcondes C., Leuch Lozovei, A., Falqueto A., Brazil R.P., Galati E.A.B., Aguiar G.M., Souza N.A. 1999. Influence of altitude, latitude and season of collection (Bergmann's rule) on the dimensions of Lutzomyia intermedia (Lutz \& Neiva, 1912) (Diptera, Psychodidae, Phlebotominae). Memorias do Instituto Oswaldo Cruz 94: 693-700.

Byers J.E. 2000. Effects of body size and resource availability on dispersal in a native and a non-native estuarine snail. Journal of Experimental Marine Biology and Ecology 248: 133-150.

Chown S.L., Klok C.J. 2003. Altitudinal body size clines: latitudinal effects associated with changing seasonality. Ecography 26: 445-455.

Cigliano M.M., Otte D. 2003. Revision of the Dichroplus maculipennis species group (Orthoptera, Acridoidea, Melanoplinae). Transactions American Entomological Society 129: 133-162

Cruz F.B., Fitzgerald L.A., Espinoza R.E., Schulte, A. 2005. The importance of phylogenetic scale in tests of Bergmann's and Rapoport's rules: lessons from a clade of South American lizards. Journal of Evolutionary Biology 18: $1559-1574$

Fischer K., Fiedler K. 2002. Reaction norms for age and size at maturity in response to temperature: a test of the compound interest hypothesis. Evolutionary Ecology 16: 333-349.

Hausdorf B. 2003. Latitudinal and altitudinal body size variation among north-west European land snail species. Global Ecology and Biogeogeography 12: 389-394. 
Hawkins B.A, Diniz-Filho J.A.F. 2004. 'Latitude' and geographic patterns in species richness. Ecography 27: 268-272.

Heinze J., Foitzik S., Fischer B., WankeT., KipyatkovV.E. 2003. The significance of latitudinal variation in body size in a holarctic ant, Leptothorax acervorum. Ecography 26: 349-355.

Honek A. 1993. Intraspecific variation in body size and fecundity in insects: a general relationship. Oikos 66: 483-492.

Huey R.B., Gilchrist G.W., Carlson M.L., Berrigan D, Serra L. 2000. Rapid evolution of a geographic cline in size in an introduced fly. Science 287: 308-309.

James F.C. 1970. Geographic size variation in birds and its relation to climate. Ecology 51: 365-390.

Johansson F. 2003. Latitudinal shifts in body size of Enallagma cyathigerum (Odonata). Journal of Biogeography 30: 29-34.

Laugen A.T., Laurila A., Jönsson K.I., Söderman F., Merilä J. 2005. Do common frogs (Rana temporaria) follow Bergmann's rule? Evolutionary Ecology Research 7: 717-731.

Laugen A.T., Laurila A., Räsänen K., MeriläJ. 2003. Latitudinal countergradient variation in the common frog (Rana temporaria) development rates - evidence for local adaptation. Journal of Evolutionary Biology 16: 996-1005.

Leemans L., Cramer W.P. 1991. The IIASA Database for Mean Monthly Values of Temperature, Precipitation, and Cloudiness on a Global Terrestrial Grid. RR-91-18. International Institute for Applied Systems Analysis, Laxenburg, Austria.

Litzgus J.D., Durant S.E., Mousseau T.A. 2004. Clinal variation in body and cell size in a widely distributed vertebrate ectotherm. Oecologia 140: 551-558.

Martí D.A. 2002. Estudios Sobre la Meiosis Masculina y Femenina en Especies Argentinas de Acrídidos (Melanoplinae). PhD. Thesis, Universidad Nacional de Córdoba, Argentina.

Masaki S. 1967. Geographic variation and climatic adaptation in a field cricket (Orthoptera: Gryllidae). Evolution 21: 725-741.

Masaki S. 1978. Seasonal and latitudinal adaptations in the life cycles of crickets, pp. 72-100. In: Dingle H. (Ed.), Evolution of Insect Migration and Diapause. Springer-Verlag, New York.

Mayr E. 1956. Geographic character gradients and climatic adaptations. Evolution 10: 105-108.

Mayr E. 1963. Animal Species and Evolution. Harvard University Press: Cambridge, MA.

Medina A.I., Martí D.A., Bidau C.J. 2007. Subterranean rodents of the genus Ctenomys (Caviomorpha, Ctenomyidae) follow the converse to Bergmann's rule. Journal of Biogeography 34: 1439-1454.

Meiri S., Dayan T. 2003. On the validity of Bergmann's rule. Journal of Biogeography 30: 331-351.

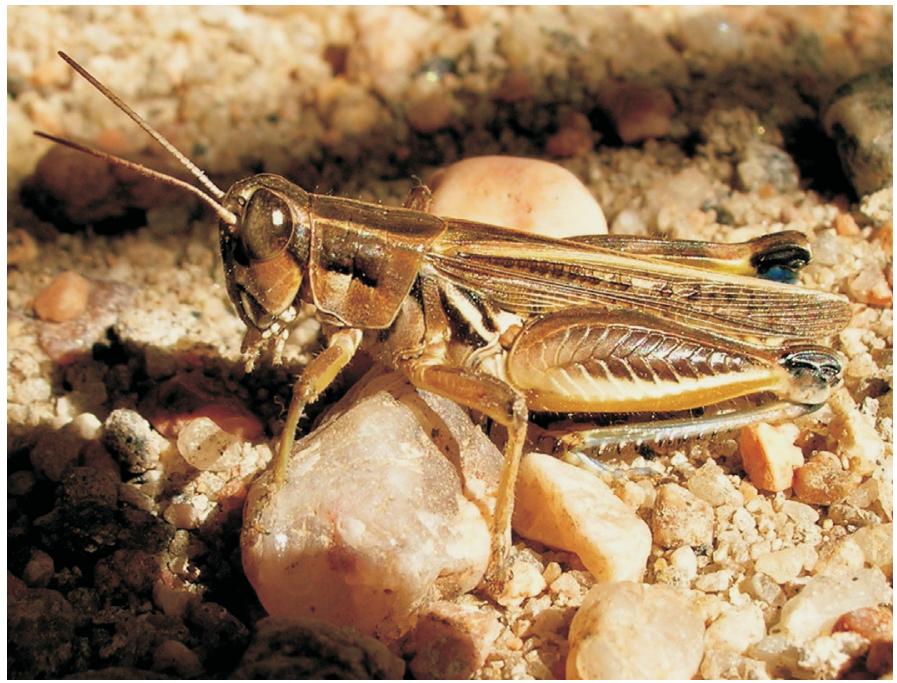

Fig. 2. Dichroplus pratensis male, natural population at Saladillo, San Luis, Argentina, summer 2006. Photo by Dardo A. Marti. See Plate IV.
Mousseau T.A. 1997. Ectotherms follow the converse to Bergmann's rule. Evolution 51: 630-632.

Murphy E.C. 1985. Bergmann's rule, seasonality, and geographic variation in body size of house sparrows. Evolution 39: 1327-1334.

Peat J., Darvill B., Ellis J., Goulson D. 2005. Effects of climate on intra- and interspecific size variation in bumble-bees. Functional Ecology 19: 145-151.

Ray C. 1960. The application of Bergmann's and Allen's rules to the poikilotherms. Journal of Morphology 106: 85-108.

Rensch B. 1938. Some problems of geographical variation and species formation. Proceedings of the Linnean Society of London 150: 275285.

Rensch B. 1959. Evolution Above the Species Level. Columbia University Press: New York

Roff D. 1980. Optimizing development time in a seasonal environment: The "ups and downs" of clinal variation. Oecologia 45: 202-208.

Rosenzweig M.L 1968. Net primary productivity of terrestrial communities: prediction from climatological data. American Naturalist 102: 67-74.

Roy K., Martien K.K. 2001. Latitudinal distribution of body size in northeastern Pacific marine bivalves. Journal of Biogeography 28: 485-493.

Schäuble C.S. 2004. Variation in body size and sexual dimorphism across geographical and environmental space in the frogs Limnodynastes tasmaniensis and L. peronii. Biological Journal of the Linnean Society 82: $39-56$

Smith R.J., Hines A., Richmond S., Merrick M., Drew A., Fargo R. 2000. Altitudinal variation in body size and population density of Nicrophorus investigator (Coleoptera: Silphidae). Environmental Entomology 29: 290-298.

Steel R.G.D., Torrie J.H. 1980. Principles and Procedures of Statistics. $2^{\text {nd }}$ Edit. McGraw-Hill: New York.

Telfer M.G., Hassall M. 1999. Ecotypic differentiation in the grasshopper Chorthippus brunneus: life history varies in relation to climate. Oecologia 121: 245-254.

Trusell G.C. 2000. Phenotypic clines, plasticity, and morphological tradeoffs in an intertidal snail. Evolution 54: 151-166.

Turk S.Z., Barrera M. 1979. Acridios del NOA III. Estudio bio-ecológico sobre siete especies del género Dichroplus Stål (Orthoptera, Acrididae). Acta Zoológica Lilloana 35: 785-805.

Walters J., Hassall M. 2006. The temperature-size rule in ectotherms: may a general explanation exist after all? American Naturalist 167: 510-523.

Zar JH 1984. Biostatistical Analysis. $2^{\text {th }}$ Edit. Prentice Hall: Englewoods Cliffs, NJ.

Zar JH 1999. Biostatistical Analysis. $4^{\text {th }}$ Edit. Prentice Hall: Upper Saddle River, NJ.

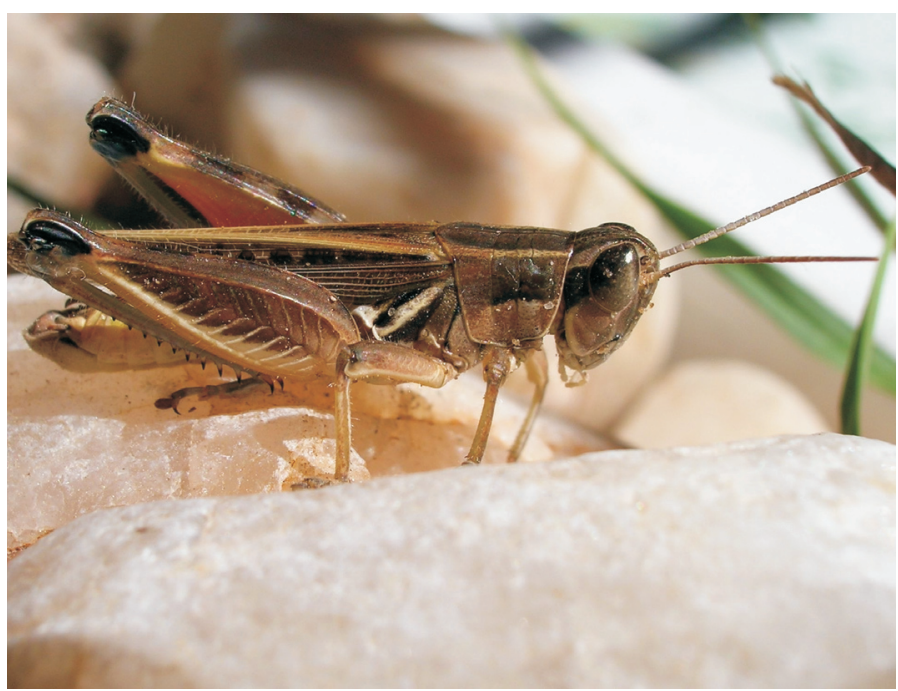

Fig. 3. Dichroplus pratensis male, as Fig. 2. See Plate IV. 